\title{
Evaluation of Medication Adherence in Adults Who Use Multiple Medications in The Context of Illness Perception, Acknowledgement and Attitude Characteristics Çoklu İlaç Kullanan Erişkinlerde Tedaviye Uyumun Hastalık Algısı, Bilgi ve Tutum Bağlamında Değerlendirilmesi Damla Demiray Kara ${ }^{* 1}$, Ertan Mert ${ }^{1}$, Yücel Uysal ${ }^{1}$, Ibrahim Başhan ${ }^{2}$
}

\begin{abstract}
Objective: In this study evaluation of medication adherence in adults who have chronic disease and use multiple medications in the context of illness perception, acknowledgement and attitude characteristics is aimed. Methods: For this purpose, Brief Illness Perception Scale (BIPS) and Modified Morisky Scale (MMS) were applied to patients and results were compared with sociodemographic characteristics and medication consumption data. Results: The data of 159 patients were collected and data of 146 patients that meet the criteria were included to analysis. Of these 146 patients $90(61,6 \%)$ were female and $56(38,4 \%)$ were male. Average age was 56,1 year $( \pm 8,2$, range $28-66$ year). The relation between BIPS and MMS scores and data of patients (gender, age, marital status, education status, people living together status and number of medication used) was searched. It was observed that BIPS scores increased with older ages and this result was statistically significant. Besides, BIPS and MMSknowledge scores were increased and MMS-motivation scores were decreased with higher number of medication used, and these results were also statistically significant. There was no statistically significant correlation between scale scores and other data of patients in terms of gender, marital status, education, people living together status. In the analysis of correlation between MMS and BIPS scores it was found that; patients who have lower MMS-motivation and MMS-knowledge scores tend to have higher BIPS scores. Although this correlation is not a causal relationship it was found statistically significant. Conclusion: It was found that BIPS and MMS introduced useful data especially in patients with chronic diseases during evaluation of medication adherence. Applying these scales routinely and making medication adherence more objective at chronic patients whose target values are unsuccessful would facilitate determination and intervention of weak points of disease management.
\end{abstract}

Key words: Ilness perception, medication adherence, multiple medication use

\section{ÖZET}

Amaç: Bu çalıșma, çoklu ilaç kullanan bir grup yetişkin kronik hastada, Kısa Hastalık Algı Ölçeği (KHAÖ) ve Modifiye Morisky Uyum Ölçeği (MMÖ) bağlamında tedavi uyumu ve hastalık algısının etkisini değerlendirmeyi amaçlamaktadır. Gereç ve Yöntem: Bu değerlendirme için, Mersin Üniversitesi Tıp Fakültesi Aile Hekimliği Polikliniğine Temmuz 2015- Temmuz 2016 tarihleri arasında başvuran vakalara, Kısa Hastalık Algı Ölçeği (KHAÖ) ve Modifiye Morisky Uyum Ölçeği (MMÖ) uygulanmıştır. Sonuçlar, vakaların farklı sosyodemografik özellikleri ile ilaç kullanım verileri bağlamında karşılaştırılmıştır. 18 yaş üstü, birden fazla ilaç kullanan, sözel iletişim kurma konusunda dil veya mental fonksiyon sorunu olmayan vakalar arasından gönüllü olanlar çalışmaya dahil edilmiştir. Bulgular: Çalışma süresince, toplam 159 vakanın verileri toplanmış, bu vakalardan kriterleri karşılayan 146'sının sonuçları analizlere dahil edilmiş ve değerlendirilmiştir. Vakaların, 90'ı kadın $(\% 61,6)$ ve 56'sı erkek $(\% 38,4)$ idi. Yaş ortalaması 56,1 yıl $( \pm 8,2,28$-66 yıl aralığında) olarak bulunmuştur. Vakaların cinsiyet, yaş, medeni durumu, eğitim durumu, birlikte yaşadığı kişi varlığı ve kullandığı ilaç sayısı, verilerinin ortalama KHAÖ ve MMÖ skorları (MMÖ-motivasyon ve MMÖ-bilgi alt skorları) ile ilişkisi araştırılmıştır. KHAÖ skorlarının yaş arttıkça azaldığı gözlendi $(\mathrm{p}<0,05)$ ve bu sonucun istatistiksel olarak anlamlı olduğu bulunmuştur. Ayrıca kullanılan ilaç sayısı arttıkça, KHAÖ ve MMÖ-bilgi skorlarının arttığı $(\mathrm{p}<0,05)$, MMÖ-motivasyon skorlarının azaldığı $(\mathrm{p}<0,05)$ ve bu sonuçlarında istatistiksel olarak anlamlı olduğu bulunmuştur. Vakaların, cinsiyet, medeni durum, eğitim durumu, birlikte yaşadığı kişi varlığı ile ölçek skorları arasında istatistiksel olarak anlamlı bir ilişki tespit edilmemiştir. MMÖ motivasyon ve bilgi düzeyi ile KHAÖ skorları arasındaki ilișkinin analizinde; düș̈̈k MMÖ-motivasyon ve düșük MMÖ-bilgi düzeyine sahip vakaların daha yüksek KHAÖ skorlarına sahip olduğu görüldü ve her ne kadar bir sebep sonuç ilişkisini göstermese de bu ilişkinin istatistiksel olarak anlamlı olduğu bulunmuştur. Sonuç: Özellikle kronik hastalığı olan vakalarda, ilaç uyumunu değerlendirmede KHAÖ ve MMÖ'nin hastalık yönetiminde fikir verebilecek faydalı veriler sunduğu belirlenmiş̧ir. Yaş arttıkça ve kullanılan ilaç sayısı azaldıkça vakaların hastalıktan etkilenme düzeyi ve hastalığı endişe verici olarak algılama düzeyleri azalmaktadır. Ayrıca kullanılan ilaç sayısı arttıkça vakaların tedaviye uyum bilgi düzeylerinin arttı̆̆ı ve motivasyon düzeylerinin azaldığı bulunmuştur. Hedef değerlere ulaşmada, sorun tespit edilen kronik hastalıklı vakalarda, bu ölçeklerin rutin olarak uygulanarak tedaviye uyumun objektif olarak ortaya konması, hastalık yönetiminde zayıf noktaların tespit edilmesini ve müdahale edilmesini olanaklı hale getirecektir.

Anahtar kelimeler: Coklu ilac kullanımı, hastalık algısı, tedaviye uyum

Received / Geliş tarihi: 05.04.2017, Accepted / Kabul tarihi: 27.07.2017

${ }^{1}$ Mersin Üniversitesi Tıp Fakültesi Aile Hekimliği Anabilim Dalı

${ }^{2}$ Mersin Üniversitesi Tıp Fakültesi Tıp Eğitimi Anabilim Dalı

*Address for Correspondence / Yazışma Adresi: Ertan Mert, Mersin Üniversitesi Tıp Fakültesi Aile Hekimliği Anabilim Dalı MersinTÜRKIYE, E-mail: drertanmert@yahoo.com

Kara DD, Mert E, Uysal Y, Başhan İ.Çoklu İlaç Kullanan Erişkinlerde Tedaviye Uyumun Hastalik Algısı, Bilgi ve Tutum Bağlamında

Değerlendirilmesi. TJFMPC, 2017; 11(4): 227-234.

DOI: $10.21763 /$ tjfmpc.359675

Kara ve ark., TJFMPC www.tjfmpc.gen.tr 2017; 11 (4) 


\section{GíRIŞ}

Günümüzde, bilim ve teknoloji alanlarında kaydedilen ilerlemeler, modern tanı ve tedavi yöntemlerinin yaygınlaşması, mortalite hızının azalması ve koruyucu hekimlik uygulamalarında etkinliğin artması sonucunda, giderek uzayan beklenen yaşam süresine bağlı olarak, kronik hastalıkların insidans ve prevalansı da giderek artmaktadır. Kronik hastalıklar; süreğen tıbbi kontrol, bakım ve tedavi gerektiren sağlık problemleri olup, genellikle çoklu ilaç tedavisi gerektirebilen durumlardır. ${ }^{1}$ Yaşın ilerlemesi ile beraber, birden fazla ilaç kullanımını gerektiren kronik hastalık sıklığı da artmaktadır. ${ }^{2}$ Özellikle süreğen ilaç tedavilerinde, tedavi başarısını belirleyen en önemli faktörlerden birisi de tedaviye uyumdur. ${ }^{3-5}$ Tedaviye uyum, hem tedavi maliyetini düşüren, hem de hastalığın seyrini etkileyen bir faktör olarak kabul edilmektedir. ${ }^{6,7}$ Kronik hastalıklarda, uzun dönem ilaç tedavisine uyum Dünya Sağlık Örgütü (DSÖ)'nün 2003 yılı verilerine göre yaklaşık \%50'dir. Gelişmekte olan ülkelerde ise bu oran daha da düşüktür. ${ }^{8}$ Tedaviye uyum, kişinin yaşam tarzını, davranışlarını, ilaç alma şeklini, tedaviye inanmasını ve sahiplenerek sürdürmesini kapsayan algı, tutum ve davranışların bileşkesi ile belirlenir. ${ }^{8,9}$ Hastanın tedaviye uyumunda, hastalık algısının yanı sıra, bilgi, istek ve motivasyonu da önemlidir. ${ }^{8}$

Bireyin, hastalık kavramına yönelik algısı, hastalığ̣ nasıl yorumladığı, ona yüklediği anlamlar, hastalık dönemleri boyunca yaşadığı veya karşılaştığı deneyimler, içeri alınmış bilgiler, duygusal ve davranışsal tepkiler, hastalık süreci, psikopatoloji ve baş etme mekanizmaları ile ilişkilidir. ${ }^{10}$ Hastalık algısı, bireyin tedaviye uyumunu doğrudan etkileyen bir faktör olarak gözükmektedir. ${ }^{11}$ Ancak önemine rağmen, tıbbi görüşme süreçlerinde kişilerin hastalıkları hakkındaki inanışları ve görüşleri nadiren sorgulanabilmektedir.

Bireyin, hastalık hakkındaki bilgi düzeyi ile tedaviye olan istek ve inancı da, tedaviye uyum sürecinde belirleyici rol oynayan faktörler arasındadır. Yeterli bilgi düzeyi, hastalıkla baş etmeyi kolaylaştırarak felaketçi algılamayı engeller ve hastalık hakkındaki tepkileri olumlu yönde etkiler. Bilginin, yetersiz olması ya da bilgi verilmemesi ise hastanın endişe düzeyini arttırarak tedavi uyumunu güçleştirebilir. ${ }^{12}$

Tedaviye uyum düzeyini, hastalık algısı, bilgi ve motivasyon bağlamında belirlemeye yönelik altın standart bir yöntem bulunmamakla beraber, bu amaç doğrultusunda geliştirilmiş anket ve ölçekler ile tedaviye uyumu değerlendirmek mümkündür. ${ }^{13}$

Kısa hastalık alg1 ölçeği (KHAÖ) dokuz madde içermektedir. KHAÖ ile hastalığı anlama, hastallktan duygusal olarak etkilenme ve tedaviye inanma düzeyleri saptanarak hastalık algı skorları belirlenmektedir. Hastalık algı skoru ile kişinin farklı parametrelere göre hastalıktan etkilenme ve hastalığ 1 endişe verici olarak algılama düzeyleri arasında pozitif bir ilişki vardır. ${ }^{14,15}$

Türkçe Modifiye Morisky Ölçeği (MMÖ) ise altı sorudan oluşan, kısa, kolay uygulanabilir, ilaç kullanma alışkanlığına yönelik bilgi ve motivasyon düzeylerini ayrı ayrı değerlendirebilen güvenilir bir testtir. MMÖ ile tedavinin yararına inanma durumu, ilaçları zamanında alma alışkanlığı ile ilaç almayı unutma ya da birakma durumu sorgulanmaktadır. ${ }^{16}$

Tedaviye uyumu etkileyen faktörlerden; hastalık algısının, tedavi bilincinin, tedavi süreçlerine olan inanç, istek ve motivasyonun, sosyodemografik ve psikosososyokültürel özellikler kapsamında değerlendirilmesinin, tedavi uyumunu arttırmaya yönelik bağlamsal ve bireysel stratejiler geliştirmeye katkı sağlayabileceği düşünüldü. $\mathrm{Bu}$ amaç doğrultusunda; çalışmamızda çoklu ilaç kullanan erişkinlerde tedaviye uyumu etkileyen faktörlerin, alg1, bilgi, tutum, istek ve motivasyon özellikleri bağlamında, KHAÖ ve MMÖ kullanılarak irdelenmesi amaçlanmıştır.

\section{GEREÇ VE YÖNTEM}

Araştırmamız, prospektif kesitsel bir anket çalışması yapısında planlanmış ve etik kurul onayı alınmıştır. Çalışmamız, Mersin Üniversitesi Tıp Fakültesi, Aile Hekimliği polikliniğine başvuran ve birden fazla ilaç kullanan 18-65 yaş arası hastalar ile Temmuz 2015 Temmuz 2016 tarihleri arasında yürütülmüştür. Çalışma süresi içinde, kriterleri karşılayan toplam 159 vaka seçim yapılmaksızın çalışmaya dahil edilmiştir. 159 vakanın, 13'ü çalışmada yer almayı kabul etmemiş veya anketi tamamlamamıştır. Araştırmaya, 90'^ kadın ve 56'sı erkek olmak üzere, toplam 146 hasta dahil edilmiştir. Sözel iletişim kuramayan, anket formunu anlayıp yanıtlayabilecek düzeyde mental kapasiteye sahip olmayan ve araştırmaya katılmayı kabul etmeyen hastalar çalışmaya dahil edilmemiştir. Çalışmada, çoklu ilaç kullanan olguların algı, bilgi, tutum, istek ve motivasyon özelliklerini değerlendirmek için, KHAÖ ve MMÖ kullanılmıştır. Çalışmanın uygulama yöntemi olarak "yüz yüze görüşme 
tekniği" benimsenmiştir. Tüm çalışma süreçleri ve veri kayıtları, tek yürütücüyle gerçekleştirilmiştir.

Katılımcıların; yaşı, cinsiyeti, eğitim düzeyi, medeni durumu, evde kaç kişiyle yaşadığı, mevcut hastalıkları, günlük kullandıkları ilaç sayısı, ilaç dozları, ilaç kullanım şekilleri, ilaçların kullanımına ve yan etkilerine ilişkin bilgi alma durumları, ilaç kullanım hataları ile ilaç prospektüslerini okuma ve anlama durumları sorgulanarak kaydedilmiştir.

Daha sonra katılımcıların hastalık algıları KHAÖ ile, tedavi uyumlarını etkileyen bilgi, istek ve motivasyon özellikleri ise MMÖ ile değerlendirilmiştir. ${ }^{14,16}$ KHAÖ dokuz madde içermektedir. Hastalık algı skoru arttıkça, kişinin farklı parametrelere göre hastalıktan etkilenme düzeyi ile hastalığı endişe verici olarak algılama düzeyi artmaktadır. Ölçeğin likert yapısındaki ilk sekiz sorusu ile; hastalıktan etkilenme, hastalık süresi, hastalığın kontrolünün kendisinde olduğuna inanma, tedaviye inanç, şikayetlerin derecesi, hastalıktan duyulan endişe, hastalığı anlama ve hastalığa verilen duygusal tepki özellikleri değerlendirilmiştir. $\mathrm{Bu}$ sekiz maddeye verilen puanlar hesaplanarak, hastalık alg1 skoru elde edilmiştir. KHAÖ'nin dokuzuncu maddesinde ise, olgulara hastalıklarına sebep olduğuna inandıkları faktörler sorulmuştur. ${ }^{14,15}$ MMÖ ise 6 sorudan oluşmaktadır. "Evet" ya da "Hayır" olarak verilen yanıtların değerlendirmesinde; 2 . ve 5 . sorularda evet cevab1 1 puan, hayır cevab1 0 puan; diğer sorularda ise evet cevabi 0 puan, hayır cevab1 1 puan olarak hesaplanmıştır. 1.,2. ve 6. sorulardan hastanın aldığı toplam puan, 0 veya 1 ise düşük motivasyon düzeyini, 1 puanın üzerindeki değerler ise yüksek motivasyon düzeyini göstermektedir. 3.,4. ve 5 . sorulardan alınan toplam puan, 0 veya 1 ise düşük bilgi düzeyini, 1 puanın üzerindeki değerler ise yüksek bilgi düzeyini göstermektedir. ${ }^{16}$

İstatistiksel analizler sırasında, vakaların farklı parametreler bağlamındaki skor değerleri arasındaki ortalamalar ve korelasyon düzeyi, eşleştirilmiş gruplar arasındaki farkların testi (Paired-Samples T Test) ile hesaplanmış, anlamlılık düzeyi olarak; 0,05'in altındaki p değerleri anlamlı kabul edilmiştir. Analizler, SPSS Statistics versiyon 16.0 ile yapılmıştır.

\section{BULGULAR}

Çalışmaya, çoklu ilaç kullanan 146 yetişkin hasta dahil edilmiş olup, çoğunluğu kadın $(\% 61,6)$ ve yaş ortalaması 56,1 yıldı. Olguların, sosyodemografik özellikleri ve ilaç kullanım örüntüleri irdelendiğinde; çoklu ilaç kullanan hasta sayısının en fazla 58-66 yaş aralığında (K:\%55,6; E:\%51,8) bulunduğu, çoğunun evli (K:\%78,9; E:\%91,1) olduğu, çoğunda birlikte yaşayan kişilerin mevcut olduğu (K:\%88,8; E:\%89,3), çoğunda algılanan sağlık durumunun orta ve iyi olarak belirtildiği (K:\%64,5; E:\%57,1) ve olguların yaklaşık yarısının ilaç prospektüsünü okumadığı $(\mathrm{K}: \% 46,7 ; \mathrm{E}: \% 51,8)$ görüldü. Prospektüs okumama nedenleri sorgulandığında; olguların \%39,4'ü gerek duymadığı için, \%28,2'si anlamaması sebebiyle, $\% 25,4$ '̈u ise görme problemi nedeniyle okuyamadığını ifade etmiştir. Olguların büyük çoğunluğu (\%96) ilaçlarını doktor önerisiyle almaktaydı, ayrıca vakaların yaklaşık yarısı (K:\%47,8; E:\%51,8) ilaç kullanım etki ve yan etkileri hakkında bilgi aldığını belirtmiştir. Bilgi alınan kaynaklar sorgulandığında; olguların \%65,3'ü doktordan, \%19,4'ü eczacıdan ve \%13,9'u ise diğer sağlık çalışanlarından bilgi aldığını ifade etmiştir. Vakaların, cinsiyetleri ile ilaç kullanımı sırasında yan etki sorunu yaşama durumlarına bakıldığında, olguların büyük çoğunluğunun (K:\%68,9; E:\%78,8) yan etki sorunu yaşamadığ

Olguların, hastalık algılarını değerlendirmek için KHAÖ uyguland, bilgi ve motivasyon düzeyleri ise MMÖ ile belirlenmiştir. Olguların, cinsiyet, yaş ve medeni durumları ile KHAÖ, MMÖ motivasyon, MMÖ bilgi skorlarının dağılımı Tablo 1'de gösterilmektedir. Çalışmamızda, cinsiyete göre KHAÖ ortalama skoru kadınlarda 41,9 $\pm 14,1$, erkeklerde 40,4 $\pm 14,2$ olarak bulunmuştur. MMÖ motivasyon skoru, kadınlarda $2,13 \pm 0,85$, erkeklerde $2,11 \pm 0,93$ olarak saptand 1 . MMÖ bilgi skorunun ise kadınlarda 2,19 $\pm 0,98$, erkeklerde 2,23 $\pm 1,02$ olduğu görülmüştür. Sonuçlarımız, vakaların cinsiyetleri ile KHAÖ, MMÖ motivasyon ve MMÖ bilgi skorları arasında istatistiksel olarak anlamlı bir ilişki bulunmadığına işaret etmektedir $(\mathrm{p}>0,05)$.

Yaş gruplarına bakıldığında, KHAÖ ortalama skorunun 28-37 yaş arasında en yüksek olduğu $(45,8 \pm 13,5)$ ve $58-66$ yaş arasında ise en düşük olduğu $(39,5 \pm 15,4)$ saptanmıştır. Vakalardan bir tanesi 65 yaş üstündeydi. Yaş arttıkça, KHAÖ ortalama skorunun azaldığ 1 ve bu ilişkinin istatistiksel olarak anlamlı olduğu görüldü $(p<0,05)$. Yaş gruplarında, MMÖ motivasyon ve bilgi skorlarının ise birbirine yakın değerlerde olduğu ve aradaki ilişkilerin istatistiksel olarak anlamlı olmadığı saptanmıştır ( $p>0,05)$. Medeni durum ile KHAÖ, MMÖ motivasyon ve bilgi skorları arasında 


\begin{tabular}{|c|c|c|c|c|c|}
\hline & $\mathbf{N}$ & $\%^{+}$ & $\begin{array}{l}\text { KHAÖ skoru } \\
\left(\text { ortalama } \pm \mathbf{S D}^{++}\right)\end{array}$ & $\begin{array}{l}\text { MMÖ-motivasyon } \\
\text { skoru } \\
(\text { ortalama } \pm \text { SD) }\end{array}$ & $\begin{array}{l}\text { MMÖ-bilgi } \\
\text { skoru } \\
(\text { ortalama } \pm \text { SD) }\end{array}$ \\
\hline Cinsiyet & & & $(\mathrm{p}>0,05)$ & $(\mathrm{p}>0,05)$ & $(\mathrm{p}>0,05)$ \\
\hline Kadın & 90 & 61,6 & $41,9 \pm 14,1$ & $2,13 \pm 0,85$ & $2,19 \pm 0,98$ \\
\hline Erkek & 56 & 38,4 & $40,4 \pm 14,2$ & $2,11 \pm 0,93$ & $2,23 \pm 1,02$ \\
\hline Yaş aralıkları & & & $(\mathrm{p}<0,05)$ & $(p>0,05)$ & $(p>0,05)$ \\
\hline 28-37 yaş arası & 7 & 4,8 & $45,8 \pm 13,5$ & $1,81 \pm 0,95$ & $1,89 \pm 1,10$ \\
\hline 38-47 yaş arası & 9 & 6,2 & $44,0 \pm 7,8$ & $2,11 \pm 0,78$ & $2,22 \pm 1,09$ \\
\hline 48-57 yaş arası & 51 & 34,9 & $43,0 \pm 12,7$ & $2,02 \pm 0,86$ & $2,27 \pm 1,04$ \\
\hline 58-66 yaş arası & 79 & 54,1 & $39,5 \pm 15,4$ & $2,15 \pm 0,74$ & $2,22 \pm 0,91$ \\
\hline Medeni durum & & & $(\mathrm{p}>0,05)$ & $(p>0,05)$ & $(p>0,05)$ \\
\hline Evli & 122 & 83,5 & $41,3 \pm 14,1$ & $2,08 \pm 0,81$ & $2,25 \pm 0,94$ \\
\hline Eşi ölmüş & 12 & 8,2 & $46,4 \pm 13,2$ & $2,09 \pm 0,90$ & $2,33 \pm 0,77$ \\
\hline Bekar & 9 & 6,2 & $37,2 \pm 12,4$ & $2,22 \pm 0,66$ & $2,00 \pm 1,31$ \\
\hline Boşanmış & 3 & 2,1 & $35,0 \pm 22,6$ & $2,00 \pm 0,57$ & $1,00 \pm 1,73$ \\
\hline
\end{tabular}

* KHAÖ: Kısa Hastalık Algı Ölçeği, ** MMÖ: Modifiye Morisky Ölçeği, ${ }^{+}$sütun yüzdesi, ${ }^{++}$SD: standart sapma

\begin{tabular}{|c|c|c|c|c|c|}
\hline & $\mathbf{n}$ & $\%^{+}$ & $\begin{array}{l}\text { KHAÖ skoru } \\
\left(\text { ortalama } \pm \mathbf{S D}^{++}\right)\end{array}$ & $\begin{array}{l}\text { MMÖ-motivasyon } \\
\text { skoru } \\
\text { (ortalama } \pm \text { SD) }\end{array}$ & $\begin{array}{l}\text { MMÖ-bilgi } \\
\text { skoru } \\
(\text { ortalama } \pm \text { SD) }\end{array}$ \\
\hline Ĕgitim durumu & & & $(p>0,05)$ & $(p>0,05)$ & $(p>0,05)$ \\
\hline Okuryazar değil & 2 & 1,4 & $47,5 \pm 19,0$ & $2,00 \pm 0,00$ & $0,50 \pm 0,70$ \\
\hline İlkokul mezunu & 57 & 39 & $42,1 \pm 14,2$ & $2,05 \pm 0,83$ & $2,14 \pm 1,00$ \\
\hline Ortaokul mezunu & 19 & 13 & $43,8 \pm 10,5$ & $2,05 \pm 0,62$ & $2,11 \pm 0,93$ \\
\hline Lise mezunu & 46 & 31,5 & $43,0 \pm 13,6$ & $2,11 \pm 0,76$ & $2,22 \pm 1,03$ \\
\hline Üniversite mezunu & 22 & 15,1 & $33,1 \pm 15,5$ & $2,14 \pm 1,03$ & $2,68 \pm 0,56$ \\
\hline $\begin{array}{l}\text { Birlikte yaşadığı } \\
\text { kişi varlığı }\end{array}$ & & & $(p>0,05)$ & $(p>0,05)$ & $(p>0,05)$ \\
\hline Evet & 130 & 89 & $41,7 \pm 14,4$ & $2,10 \pm 0,80$ & $2,22 \pm 0,93$ \\
\hline Hayır & 16 & 11 & $37,0 \pm 11,2$ & $2,00 \pm 0,81$ & $2,19 \pm 0,96$ \\
\hline $\begin{array}{l}\text { Kullandığı ilaç } \\
\text { sayısı }\end{array}$ & & & $(\mathrm{p}<0,05)$ & $(\mathrm{p}<0,05)$ & $(\mathrm{p}<0,05)$ \\
\hline 2-3 ilaç kullananlar & 68 & 46,6 & $38,1 \pm 15,3$ & $2,23 \pm 0,82$ & $1,94 \pm 0,82$ \\
\hline 4-5 ilaç kullananlar & 47 & 32,2 & $42,1 \pm 11,8$ & $2,09 \pm 0,73$ & $2,18 \pm 0,75$ \\
\hline 6-8 ilaç kullananlar & 31 & 21,2 & $45,7 \pm 13,2$ & $1,84 \pm 0,89$ & $2,38 \pm 0,86$ \\
\hline
\end{tabular}

* KHAÖ: Kısa Hastalık Algı Ölçeği, ${ }^{* *}$ MMÖ: Modifiye Morisky Ölçeği ${ }^{+}$sütun yüzdesi, ${ }^{++}$SD: standart sapma 
da istatistiksel olarak anlamlı bir ilişki bulunamamıştır $(p>0,05)$. Ayrıca, olguların eğitim durumu, birlikte yaşadığı kişi varlığı ve kullandığı ilaç sayısı ile KHAÖ, MMÖ motivasyon ve MMÖ bilgi skorlarının dağılımı da incelenmiştir (Tablo 2).

Vakaların eğitim durumu ile KHAÖ skorlarının dağılımına bakıldığında, KHAÖ ortalama skorunun okuryazar olmayan grupta en yüksek olduğu $(47,5 \pm 19,0)$ üniversite mezunu olan grupta ise en düşük olduğu $(33,1 \pm 15,5)$ görülmüştür. Ancak, aradaki bu fark istatistiksel olarak anlamlı değildi ( $\mathrm{p}>0,05)$. Eğitim durumu ile MMÖ skorlarının dağılımına bakıldığında, okuryazar olmayan grupta MMÖ bilgi skoru diğer gruplara göre düşük saptanmış olmakla beraber, aradaki farklar istatistiksel olarak anlamlı bulunmamıştır $(\mathrm{p}>0,05)$.

Vakaların, birlikte yaşadığı kişi varlığ 1 ile KHAÖ, MMÖ motivasyon ve MMÖ bilgi skorlarının dağılımında da istatistiksel olarak anlamlı bir fark saptanmamıştır $(\mathrm{p}>0,05)$.

Vakaların kullandığı ilaç sayısı ile KHAÖ, MMÖ motivasyon ve MMÖ bilgi skorlarının dağılımına bakıldığında; KHAÖ ortalama skorunun günde 6-8 ilaç kullanan grupta en yüksek (45,7 \pm $13,2)$ olduğu ve 2-3 ilaç kullanan grupta ise en düşük $(38,1 \pm 15,3)$ olduğu görülmüştür. Günlük kullanılan ilaç sayısı arttıkça, KHAÖ ortalama skorunun da yükseldiği ve aralarındaki bu ilişkinin istatistiksel olarak anlamlı olduğu saptanmıştır $(\mathrm{p}<0,05)$. MMÖ motivasyon ortalama skorunun günde 2-3 ilaç kullanan vakalarda en yüksek $(2,23 \pm 0,82)$ ve $6-8$ ilaç kullanan grupta ise en düşük $(1,84 \pm 0,89)$ olduğu bulunmuştur. Günlük kullanılan ilaç sayısı arttıkça, MMÖ motivasyon ortalama skorunun azaldığı ve aralarındaki bu ilişkinin istatistiksel olarak anlamlı olduğu belirlenmiştir $(\mathrm{p}<0,05)$. MMÖ bilgi ortalama skoru ise günde 6-8 ilaç kullanan vakalarda en yüksek $(2,38 \pm 0,86), 2-3$ ilaç kullanan grupta ise en düşük bulunmuştur $(1,94 \pm 0,82)$. Günlük kullanılan ilaç sayısı arttıkça, MMÖ bilgi ortalama skorunun da $\operatorname{arttığ1}$ ve aralarındaki bu ilişkinin istatistiksel olarak anlamlı olduğu görülmüştür $(\mathrm{p}<0,05)$.

Çalışmada, yaş ve kullanılan ilaç sayısının KHAÖ skorlarını istatistiksel olarak anlamlı düzeyde etkilediği bulunmuştur. $\mathrm{Bu}$ bağımsız parametrelerin, KHAÖ skorları üzerindeki toplu etkisini araştırmak amacıyla yapılan çoklu regresyon analizinde elde ettiğimiz katsayılar göstermiştir ki; kullanılan ilaç sayısı, yaşa kıyasla, KHAÖ skorları üzerinde çok daha yüksek etkiye sahip olduğu tespit edilmiştir.

Olguların, MMÖ motivasyon ve bilgi düzeyleri ile KHAÖ skorlarının dağılımına bakıldığında; düşük MMÖ motivasyon ve bilgi düzeyi olanların KHAÖ ortalama skoru (46,4 $\pm 14,5$; $46,7 \pm 15,1)$, yüksek MMÖ motivasyon ve bilgi düzeyi olanların KHAÖ ortalama skoruna göre (40,1 $\pm 12,8 ; 39,5 \pm 13,3)$ istatistiksel olarak anlaml düzeyde daha yüksek olduğu saptanmıştır $(p<0,05)$ (Tablo 3).

\begin{tabular}{|l|l|l|l|}
\hline \multicolumn{3}{|c|}{ Tablo 3. Olguların MMÖ* motivasyon ve bilgi düzeyleri ile KHAÖ** ortalama skorlarının dağılımı } \\
\hline & $\mathbf{N}$ & $\boldsymbol{\%}^{+}$ & $\begin{array}{l}\text { KHAÖ skoru } \\
\left(\text { ortalama } \pm \text { SD }^{++}\right)\end{array}$ \\
\hline MMÖ motivasyon düzeyi & & & $(\mathrm{p}<0,05)$ \\
\hline $\begin{array}{l}\text { Düşük motivasyon düzeyi } \\
\text { (skor } \leq 1)\end{array}$ & 28 & 19,2 & $46,4 \pm 14,5$ \\
\hline $\begin{array}{l}\text { Yüksek motivasyon düzeyi } \\
\text { (skor >1) }\end{array}$ & 118 & 80,8 & $40,1 \pm 12,8$ \\
\hline MMÖ bilgi düzeyi & & & $(\mathrm{p}<0,05)$ \\
\hline Düşük bilgi düzeyi (skor $\leq 1)$ & 37 & 25,3 & $46,7 \pm 15,1$ \\
\hline Yüksek bilgi düzeyi (skor >1) & 109 & 74,7 & $39,5 \pm 13,3$ \\
\hline
\end{tabular}

* MMÖ: Modifiye Morisky Ölçeği ${ }^{* *}$ KHAÖ: Kısa Hastalık algı Ölçeği ${ }^{+}{ }^{+}$sütun yüzdesi, ${ }^{++}$SD: standart sapma 
Uysal ve Akpınar'ın, Tip 2 diyabetli hastalar üzerine yaptığı bir çalışmada ise, yaş ile hastalık algısı arasında anlamlı bir ilişki saptanamamıştır. ${ }^{25}$ Belirtilen çalışmada spesifik bir hastalığa odaklanılmasına bağlı olarak, yapılan periyodik sağlik kontrolleri ile, bilgilendirme ve bilinçlendirmede sürekliliğin sağlanmış olabileceği ve sonuçta yaşın ilerlemesi ile hastalık algı skorunda anlamlı bir düşüşün izlenmemiş olabileceği düşünülmüştür.

Çoklu ilaç kullanan ve araştırmamıza katılan olguların medeni durum, eğitim durumu ve birlikte yaşadığı kişi varlığı ile KHAÖ arasındaki ilişki ise istatistiksel olarak anlamlı bulunmamıştır $(\mathrm{p}>0,05)$. Bu bulgularımız literatürle benzerlik göstermektedir. ${ }^{26}$

Çalışmamızdaki en somut bulgulardan birisi; kullanılan ilaç sayısı arttıkça KHAÖ ortalama skorunun da arttığı ve kullanılan ilaç sayısıyla KHAÖ skoru arasındaki bu ilişskinin istatistiksel olarak anlamlı olduğudur $(p<0,05)$. Çoklu ilaç kullanan kişiler, genellikle komplike ve/veya çoklu kronik hastalığı olan bireylerdir. Kullanılan ilaç sayısı arttıkça hastalık algı ölçeği skoru yükselmekte ve bireylerin hastalıktan etkilenme düzeyleri ile hastalığı endişe verici olarak algılama düzeyleri de artmaktadır.

KHAÖ ile hastalığa neden olduğuna inanılan faktörler sorgulandığında; olguların yaklaşık yarısı $(\% 46,5)$ hastalıklarından stres ve beslenme alışkanlıklarını sorumlu tutmuşlardır. Hasta hekim görüşmelerinde, bireylerin yaşam tarzı özelliklerinin ve sağlık inanışlarının da irdelenmesinin, yaşam tarzı değişiklik önerilerinde bulunulması ve yanlış inanışların düzeltilebilmesi açısından önemli bir firsat olabileceği düşünüldü.

Çalışmamızda, çoklu ilaç kullanan olguların tedavi uyumlarını, bilgi ve motivasyon bağlamında değerlendirmek için MMÖ kullanılmıştır. MMÖ ile bilgi düzeyi; hastaların ilacı kesip kesmemesi ve süreğen tedavinin uzun dönem yararlarını anlayıp, anlamaması araştırılarak saptanmıştır. Motivasyon düzeyi ise unutkanlık ve dikkatsizlik sorgulanarak belirlenmiştir.

Olgularımızın, yaş gruplarına göre MMÖ bilgi ve motivasyon skorları incelendiğinde; MMÖ ortalama skorlarının yaş ilerledikçe artma eğiliminde olduğu ancak aradaki ilişkinin istatistiksel olarak anlamlı olmadığı görülmüştür $(p>0,05)$. Lee ve arkadaşlarının daha geniş hasta sayıları ile yaptıkları bir çalışmada ise, yaşla tedavi uyumu arasında anlamlı bir ilişki bildirilmiştir. Çalışmamızdaki vaka sayısının nispeten düşük olması nedeniyle, bu ilişkinin istatistiksel olarak anlamlılık düzeyine ulaşmamış olabileceği düşünülmüştür. ${ }^{27}$

Kullanılan ilaç sayısı ile, MMÖ ortalama skorları arasındaki ilişki irdelendiğinde; MMÖ-bilgi ortalama skorunun günde 6-8 ilaç kullanan olgularda en yüksek olduğu ve 2-3 ilaç kullanan grupta ise en düşük olduğu saptanmıştır. Günlük kullanılan ilaç sayısının artmasıyla, MMÖ-bilgi ortalama skorunun da $\operatorname{arttı̆̆}_{1}$ ve aralarındaki ilişkinin istatistiksel olarak anlamlı olduğu görülmüştür $(p<0,05)$. MMÖmotivasyon ortalama skoru ise günde 2-3 ilaç kullanan olgularda en yüksek, 6-8 ilaç kullanan grupta en düşük bulunmuştur. Günlük kullanılan ilaç sayısı artarken, MMÖ-motivasyon ortalama skoru azalmakta olup, kullanılan ilaç sayısıyla MMÖmotivasyon ortalama skoru arasındaki bu ilişki istatistiksel olarak anlamlı bulunmuştur $(\mathrm{p}<0,05)$. Çoklu sayıda ve dozda ilaç kullanılması ve tedaviye yeni ilaçların eklenmesi ile bir yandan hastanın tedavi bilinci artarken, diğer taraftan tedaviyi sahiplenip sürdürme isteği azalıyor olabilir. $\mathrm{Bu}$ paradoks literatüre de yansımış olup; bildirilen çalışmaların bir kısmında kullanılan ilaç sayısındaki artışın tedaviye uyumu azalttığı, bazılarında ise tam tersine arttırdığ belirtilmiştir. $^{28-31}$

Çalışmamızda, vakaların MMÖ skorları ile KHAÖ skorları arasında da istatistiksel olarak anlamlı bir korelasyon bulunmuştur (Tablo 3). Bu korelasyon bu iki ölçek arasındaki neden sonuç ilişkisini göstermemekle beraber; düşük MMÖ bilgi ve motivasyon düzeyine sahip vakaların daha yüksek KHAÖ skorlarına sahip olma eğiliminde olduğuna işaret etmektedir. Bu iki bağımlı değişken, kendilerini etkileyen farklı parametreler tarafindan farklı yönlere doğru değişim göstermektedirler. Her ne kadar çalışmamızda bu bağımlı değişkenleri etkileyen parametrelerin tamamı araştırılmamışsa da, bu iki ölçek arasındaki kuvvetli ve anlamlı korelasyon göstermektedir ki; tedavi uyumunu bilgi ve motivasyon perspektifinde değerlendirme ölçeği MMÖ ile hastalık algısını inanç, bilgi, endişe ve emosyonel durum perspektifinde belirleme ölçeği KHAÖ arasındaki ilişkileri daha ayrıntılı araştırmanın, tedaviye uyumu daha kapsamlı değerlendirmeye ve tedavi hedeflerine ulaşmaya yönelik bağlamsal stratejiler geliştirmeye katkısı olacaktır.

Çalışmamızın sınırlılıkları; olgu sayımızın spesifik hastalık alt gruplarını irdeleyecek yeterlilikte olmaması ve bu nedenle bağımlı değişkenleri etkileyen parametrelerin tamamının araştırılamamış olması şeklinde özetlenebilir. Hastalıklar ile tedaviye uyum arasındaki ilişkinin belirlenebilmesi açısından daha geniş çalışmalara ihtiyaç bulunmaktadır. 


\section{SONUÇ}

Düşük örneklem sayısı, hastalık algısını ve tedaviye uyumu etkileme potansiyeline sahip diğer faktörlerin çalışmaya dahil edilememesi, çalışmanın kısıtlılıkları olarak kabul edilmektedir. Sonuç olarak, çalıșma verilerimiz; kullanılan ilaç sayısı arttıkça bireylerin hastalığ 1 endişe verici olarak algılama düzeylerinin de arttığına ve kullanılan ilaç sayısı ile tedaviye ilişkin bilgi düzeyleri arasındaki doğru orantılı ilişkiye rağmen, artan ilaç sayısı ile tedaviye inanç, istek ve uyum motivasyonlarının anlamlı düzeyde düştüğüne işaret etmektedir. Bu sebeple; bakımda süreklilik prensibine göre yapılandırılmış periyodik sağlik kontrollerinde, tedaviye uyumun alg1, bilgi ve motivasyon bağlamında değerlendirilmesi ve gerekli düzeltici müdahalelerin yapılması, arzu edilen tedavi başarısının sağlanabilmesi açısından önemlidir. Hedef değerlere ulaşmada sorun tespit edilen kronik hastalarda, KHAÖ ve MMÖ'nin rutin olarak uygulanarak tedaviye uyumun objektif olarak ortaya konması, hastalık yönetiminde zayıf noktaların tespit edilerek düzeltilmesini olanaklı hale getirecektir. Ayrıca, verilerimiz tedavi süreçlerinin yönetiminde, hekimin belirleyici ve aydınlatıcı rolünün de, tedaviye uyumu pozitif yönde etkilediğini göstermektedir.

Aile Hekimliğinde öncelikli noktalardan biri olan 'kapsamlı bakım' bağlamında; vakaların hastalıklarının tanısı ve uygun şekilde tedavilerini planlamanın ötesinde, bireylerin hastalık algıları ve onlara önerilen tedaviye ne derece uyum gösterdiklerinin değerlendirilmesi ve takibi, hekimin hastalık yönetim başarısında belirleyici faktörler arasındadir.

\section{KAYNAKLAR}

1. Güç MO. İlaç tedavisinin temel ilkeleri. Gökçe Kutsal Y, Çakmakçı M, Ünal S, editörler. Geriatri 1. Ankara: Hekimler Yayın Birliği; 1997. p.65-75.

2. Halil M. Yaşlı hastalarda polifarmasi. Arığul S, editör. Geriatri ve gerontoloji. MN Medikal \& Nobel Tip Kitapevleri; 2006. p.393-400.

3. Veazie PJ, Cai S. A connection between medication adherence, patient sense of uniqueness, and the personalization of information. Medical Hypotheses 2007;68(2):335-342.

4. Balon R. Managing Compliance. Psychiatric Times. 2002;19(5):1-2. www.psychiatrictimes.com /articles/ managingcompliance (erişim: 02.04.2017).

5. Grisel JE, Rasmussen PR, Sperry L. Anxiety and depression: Physiological and pharmacological considerations. The Journal of Individual Psychology 2006;62(4):398-416.
6. Mauskopf JA, David K, Grainger DL, et al. Annual health outcomes and treatment costs for schizophrenic populations. J Clin. Psychiatry 1999;(Suppl 19):14-19.

7. Ozsahin AK, Haydardedeoğlu FE. Barriers to drug adherence. TJFM\&PC 2016;10(2):58-62.

8. Guidelines from the Case Management Society of America for improving patient adherence to medication therapies. Case Management Society of America Version 2. June 2006. p. 1112. www.cmsa.org/portals /0/pdf/cmag2.pdf (erişim: 02.04.2017)

9. Domaç M, Hayran O, Dülger GA, Balta E, Özkan O. Türkiye'de hipertansiyonlu hastaların tedaviye uyumu ve antihipertansif kullanım özellikleri. Türk Eczacılar Birliği Araştırma Yayınları Dizisi. Ankara, 2000; 3.

10. Küçükbakar, A. Kanser tanısını yeni alan ve hastalığ1 tekrarlayan bireylerin hastalığ1 algılamalarının belirlenmesi. Yüksek Lisans Tezi. Hacettepe Üniversitesi Sağlık Bilimleri Enstitüsü. Ankara: Adnan Ötüken İl Halk Kütüphanesi [362.19 KÜÇ 2011] (1).

11. Kocaman N, Özkan M, Armay Z, Özkan S. Hastalık algısı ölçeğinin Türkçe uyarlamasının geçerlilik ve güvenilirlik çalışması. Anadolu Psikiyatri Dergisi 2007;8:271-280.

12. Mete HE. Kronik hastalik ve depresyon. Klinik Psikiyatri 2008;11(Ek 3):3-18.

13. Vik SA, Maxwell CJ, Hogan DB, Patten SB, Johnson JA, Slack LR. Assessing medication adherence among older persons in community settings. Can J Clin Pharmacol 2005;12:E152E164.

14. Broadbent E, Petrie KJ, Main J, Weinman J. The brief illness perception questionnaire. J Psychosom Res 2006;60(6):631-637.

15. van Oort L, Schröder C, French DP. What do people think about when they answer the Brief Illness Perception Questionnaire? A 'thinkaloud' study. Br J Health Psychol 2011;16(2):231-245.

16. Vural B, Teberru Acar Ö, Topsever P, Filiz TM. Modifiye Morisky Ölçeğinin Türkçe geçerlilik güvenilirlik çalışması. Turkish Family Physician 2012; 3(4):17-20.

17. Esengen Ş, Seçkin Ü, Borman P, Bodur H, Yücel M, Huzur evinde yaşayan bir grup yaşlıda fonksiyonel-kognitif değerlendirme ve ilaç kullanımı. Turkish Journal Of Geriatrics 2000;3(1): 6-10.

18. Arslan GG, Eşer İ. Yaşlıların kendi kendine ilaç kullanımına uyumu ve hemşirenin rolü. Ege Üniversitesi Hemşirelik Yüksekokulu Dergisi 2005; 21(2):147-157.

19. Carrion PG, Swan A, Cecil HK, et al. Compliance with clinic attendance by outpatients with schizophrenia. Hosp Community Psychiatry 1993;44(8):764-7. 
20. Ertemür E, Erdil F. Cerrahi kliniklerinde yatan yaşlı hastaların ilaç kullanımına yönelik bilgi ve uygulamalarının belirlenmesi. Türk Geriatri Dergisi 2012;15(2): 201-207.

21. Arslan S, Şemin S. Sağlık ocağına başvuran hastaların reçetede yazılan ilaçları kullanımı ve bunu etkileyen etmenler. Sağlık ve Toplum 2005;15(1):57- 64 .

22. Neafsey PJ and Shellmann J. Adverse selfmedication practise of older adults with hypertension attending blood pressure clinics: adverse self-medication practices. The Internet Journal of Mental Health 2000; 1(1):1-9.

23. Weinman J, Petrie KJ, Moss-Morris R, Horne $\mathrm{R}$. The illness perception questionnaire: a new method for assessing the cognitive representtation of illness. Psychol Health 1996; 11:431-445.

24. Alsén P, Brink E, Persson LO, Brändström Y, Karlson BW. Illness perceptions after myocardial infarction: relations to fatigue, emotional distress, and health-related quality of life. J Cardiovasc Nurs 2010;25(2):E1-E10.

25. Uysal Y, Akpınar E. Tip 2 Diyabetli Hastalarda Hastalık Algisı ve Depresyon. Cukurova Medical Journal 2013;38(1):31-40.
26. Gündüz F, Karabulutlu EY. Tip 2 diyabetes mellituslu hastalarda hastalık alg1s1, psikososyal uyum ve glisemik kontrolün değerlendirilmesi. Anadolu Hemşirelik ve Sağlık Bilimleri Dergisi 2016;19(2):106-115.

27. Lee GK, Wang HH, Liu KQL, et all. Determinants of medication adherence to antihypertensive medications among a Chinese population using Morisky Medication Adherence Scale. PLoS One 2013;8(4):62775.

28. Claxton AJ, Cramer J, Pierce C. A systematic review of the associations between dose regimens and medication compliance. Clin Ther 2001;23:1296-1310.

29. Hassan NB, Hasanah CI, Foong K, et al. Identification of psychosocial factors of noncompliance in hypertensive patients. J Hum Hypertens 2006;20:23-29.

30. Al-Mehza AM, Al Muhailije FA, Khalfan MM, Al-Yahya AA. Drug Compliance among Hypertensive Patients; an Area Based Study. Eur J Gen Med 2009;6(1): 6-10.

31. Akıcı A. Akılcı ilaç kullanımı ilkeleri doğrultusunda yaşlılarda reçete yazma ve Türkiye'de yaşlılarda ilaç kullanımı boyutları. Turk J Geriatr 2006;Özel Sayı:19-27. 